\title{
Antibiogram of CoPS and CoNS Isolated from Bovine Mastitis in Banaskantha District of Gujarat, India
}

\author{
R.D. Singh ${ }^{1 *}$, B.I. Prajapati ${ }^{2}$, S.K. Mody ${ }^{1}$, H.B. Patel ${ }^{1}$, S.S. Deokar ${ }^{2}$, B.A. Solanki ${ }^{2}$, \\ S.P. Desai ${ }^{3}$, V.L. Solanki ${ }^{3}$, P.M. Chauhan ${ }^{3}$ and R.R. Momin ${ }^{4}$ \\ ${ }^{1}$ Department of Pharmacology \& Toxicology, CoVSc \& AH, SDAU, \\ Sardarkrushinagar, Gujarat - 385506, India \\ ${ }^{2}$ Department of Veterinary Public Health and Epidemiology, \\ CoVSc \& AH, SDAU, Gujarat, India \\ ${ }^{3}$ Teaching Veterinary Clinical Complex, CoVSc \& AH, SDAU, Deesa, Gujarat, India \\ ${ }^{4}$ Regional Animal Disease Investigation Center (RADIC), CoVSc \& AH, SDAU, Gujarat, India \\ *Corresponding author
}

\section{A B S T R A C T}

\begin{tabular}{|c|c|}
\hline $\begin{array}{l}\text { Ke y w o r d s } \\
\text { Antibiogram, } \\
\text { Bovine mastitis, } \\
\text { Coagulase positive } \\
\text { and Coagulase } \\
\text { negative } \\
\text { staphylococci. }\end{array}$ & $\begin{array}{l}\text { Bovine mastitis poses great economic threat to dairy industry affecting livestock farmers } \\
\text { across the globe. Various species of staphylococci bacteria are one of the major pathogen } \\
\text { responsible for the bovine mastitis. The present investigation was carried out to assess in } \\
\text { vitro antibiogram of field isolates of coagulase positive and coagulase negative } \\
\text { staphylococci (CoPS and CoNS, respectively), isolated from } 95 \text { bovine mastitis cases in } \\
\text { Banaskantha district of Gujarat state. Milk samples were screened for the presence of } \\
\text { Staphylococcus species by cultural, colonial, microscopic and biochemical characteristics }\end{array}$ \\
\hline Article Info & \\
\hline $\begin{array}{l}\text { Accepted: } \\
07 \text { September } 2017 \\
\text { Available Online: } \\
10 \text { October } 2017\end{array}$ & $\begin{array}{l}\text { were } S \text {. aureus as confirmed by PCR. Antibiogram trend against nine commonly used } \\
\text { antimicrobial drugs for treatment of bovine mastitis in the region showed that both CoPS } \\
\text { and CoNS groups were highly resistant to penicillin-G ( } 83.33 \text { and } 88.24 \% \text {, respectively) } \\
\text { and tetracycline ( } 83.33 \text { and } 76.47 \% \text {, respectively). }\end{array}$ \\
\hline
\end{tabular}

\section{Introduction}

Bovine mastitis is one of the major ill-health of cattle and buffaloes, responsible for great economic loss to dairy industry affecting livestock farmers worldwide. The major economic consequences of clinical bovine mastitis are due to treatment, loss in milk production, culling, changes in product quality and the risk of other diseases (Halasa et al., 2007). For etiological diagnosis of bovine mastitis, staphylococci are divided into coagulase-positive staphylococci (CoPS) and coagulase-negative staphylococci (CoNS) based on the ability to coagulate rabbit plasma. CoPS are almost solely represented by Staphylococcus aureus, an important cause of udder infections in dairy herds (Barkema et al., 2006). Although, pathogenic $S$. aureus are coagulase positive, but some strains of $S$. aureus are also reported to be coagulase negative which causes mastitis in dairy 
animals (Fox et al., 1996). CoNS group of bacteria which comprises of more than 40 species (important are $S$. chromogenes, $S$. epidermidis, $S$. intermedius, $S$. warneri, $S$. haemolyticus, S. sciuri and S. xylosus), are often responsible for causing sub-clinical mastitis but many reports now reveals that CoNS are also causing clinical mastitis, mostly with mild form. CoNS are normal inhabitant of udder skin, teat canal and milkers' hand; thus, they are regarded as opportunistic, nosocomial and emerging pathogen (Pyorala and Taponen, 2009; Taponen and Pyorala, 2009; El-Jakee et al., 2013). Effectiveness of antibiotic therapy to treat bovine mastitis has been demonstrated to be compromised due to induction of antibiotic resistance and formation of biofilms which can be produced by both CoPS and CoNS (Babra et al., 2013; Darwish and Asfour, 2013: Tiwari et al., 2013; Al-Rubaye et al., 2016). Among many reasons behind failure of successful treatment of bovine mastitis, one is the failure of appraisal of the antimicrobial resistant pattern of pathogens involved (Du Preez, 2000). Thus, appraising the emerging antimicrobial resistant strains of pathogens is an important facet in effective mastitis therapy. Hence, the present investigation was carried out to isolate, identify and assess in vitro antibiogram of field isolates of CoPS and CoNS derived from clinical bovine mastitis cases of Banaskantha district of Gujarat, India. For generating antibiogram trend, nine commonly used antimicrobials were selected decisively based on their usage pattern for the treatment of bovine mastitis in the same region.

\section{Materials and Methods}

\section{Study area and sample details}

The present study was carried in Banaskantha district of North Gujarat State, home to Banas Dairy which ranks first in Asia in terms of milk procurement. Milk samples of 95 bovine mastitis cases were collected aseptically from all quarters of infected animals presented at Government Veterinary Dispensaries, Animal health division of Banas Dairy Co-operative Ltd., and Teaching Veterinary Clinical Complex, Deesa, Veterinary College, SDAU, Sardarkrushinagar, from October 2015 to March 2017.

\section{Cultural and biochemical characteristics}

The bacteria were isolated in BHI agar by spreading heavy inoculums of thoroughly mixed milk after incubated at $37^{\circ} \mathrm{C}$ for 24 hours. Bacteria on BHI medium were identified tentatively according to conventional methods including Gram stain staining, colony morphology and catalase test as per standard methods described by Buchanan and Gibson (1974) and Barrow and Feltham (1993). Thereafter, colonies showing Gram positive, cocci in bunches indicative of presumptive Staphylococcus spp. were transferred to its selective medium Mannitol Salt Agar (MSA).

The growth on MSA was assumed to be of Staphylococcal colonies. Finally, differentiation of coagulase positive and coagulase negative staphylococci was done by tube coagulase method. The colonies forming yellow colouration on MSA indicative of mannitol fermentation and coagulase positive isolates were assumed to be $S$. aureus and subjected to PCR confirmation.

\section{PCR confirmation of Staphylococcus spp. and Staphylococcus aureus}

The DNA extractions of isolated Staphylococcus spp. were done using the protocol of QIAGEN DNeasy blood and tissue kit. A loop full of culture grown overnight in $4 \mathrm{ml} \mathrm{BHI}$ broth at $37^{\circ} \mathrm{C}$ was used to isolate the DNA. Molecular confirmation of Staphylococcal spp. was done by genus specific 16S-rDNA gene amplification 
(Lovseth et al., 2004) while specific genotypic confirmation of Staphylococcus aureus were carried out using species specific sa442 gene amplification (Martineau et al., 1998; Bhagat et al., 2017). Detail of primers used for PCR reaction is presented in Table 1.

The PCR cycling condition for 16S-rDNA gene was subjected to 30 cycles consisting at $94^{\circ} \mathrm{C}$ for $5 \mathrm{~min}$ followed by denaturation $94^{\circ} \mathrm{C}$ for $30 \mathrm{sec}$ followed by annealing $60^{\circ} \mathrm{C}$ for $30 \mathrm{sec}$ followed by extension at $72^{\circ} \mathrm{C}$ for 1 min and final extension at $72^{\circ} \mathrm{C}$ for $5 \mathrm{~min}$. while cycling condition for $\mathrm{Sa} 442$ gene was same as $16 \mathrm{~S}-\mathrm{rDNA}$ gene with slight change in annealing temperature at $55^{\circ} \mathrm{C}$ for $30 \mathrm{sec}$ and final extension at $72^{\circ} \mathrm{C}$ for $7 \mathrm{~min}$. The PCR product was visualized on a $1.5 \%$ agarose gel using ethidium bromide and a UV transilluminator (Bhagat et al., 2017).

\section{Method for antibiogram of Staphylococcus isolates}

All the isolates obtained were subjected to in vitro antibiotic sensitivity test, as per the method described by Bauer et al., (1966) with different antibiotic discs i.e. AmoxycillinClavulanate $(30 \mathrm{mcg})$, Ampicillin-Sulbactam (10/10 mcg), Ciprofloxacin (30 mcg), Enrofloxacin $(10 \mathrm{mcg})$, Gentamicin $(10 \mathrm{mcg})$ and Penicillin G (10 Units).

The sensitivity patterns of isolates to different antibiotic disc was read by measuring the diameter of zone of inhibition as per chart provided by manufactures and classified as sensitive, intermediate and resistant.

Quantitative determination of susceptibility of Staphylococcus spp. against remaining three antimicrobials i.e. ceftizoxime, ceftriaxone and tetracycline were performed by e-test using Ezy MIC ${ }^{\mathrm{TM}}$ strips (HiMedia Lab. Pvt. Ltd., Mumbai) as per guidelines of manufacturers (CSLI, 2012).

\section{Results and Discussion}

Out of total 95 bovine mastitis milk samples collected, 52 samples were from cattle and 43 were from buffaloes. Out of 52 cow mastitis cases, 19 were of mild to severe clinical cases whereas 33 cases were of sub-clinical nature; whereas among 43 buffalo cases, 32 were clinical and 11 were of sub-clinical mastitis.

After screening of all milk samples with cultural and biochemical examination, 29 samples $(30.53 \%)$ were found positive for Staphylococcus species. Then coagulase test was performed on all 29 samples, out of which 12 samples were found positive (CoPS; $41.38 \%$ ) whereas 17 samples were found negative (CoNS; 58.62\%). DNA samples extracted from bacterial growth were also subjected to PCR and were confirmed as Staphylococcus species. Then, all 12 samples showing coagulase positive reaction were subjected to PCR for species confirmation using Sa442 gene amplification, and all 12 CoPS isolates were confirmed as Staphylococcus aureus. In present study, $30.53 \%$ of bovine mastitis cases were found to be associated with Staphylococcus species whereas higher prevalence $(45 \%)$ for same pathogen was reported in a meta-analysis of major mastitis pathogens in dairy cattle in India from year 2005 to 2016 (Krishnamoorthy et al., 2017).

Antibiogram trend against nine commonly used antimicrobial drugs for treatment of bovine mastitis in the Banaskantha district is presented in Table 2. Antibiogram study showed that, among the 29 isolates, three isolates were susceptible and five were resistant to all the antimicrobials used in this study.

Aminopenicillins in combination with betalactamase inhibitors i.e. amoxycillinclavulanate and ampicillin-sulbactam were the most effective antimicrobial agents among 
the tested drugs in vitro against CoPS group. The use of beta-lactamase inhibitors could be the possible reasons for more effectiveness of these combinations by bacterial escaping of drug resistance to some extent.

Table.1 Detail of primers for amplification of 16S-rDNA and sa442 genes employed in Polymerase Chain Reaction

\begin{tabular}{|c|l|c|c|}
\hline \multirow{2}{*}{$\begin{array}{c}\text { Gene } \\
\text { designated }\end{array}$} & \multicolumn{2}{|c|}{ Primer sequence (5' - 3') } & $\begin{array}{c}\text { Size of } \\
\text { amplified } \\
\text { products (bp) }\end{array}$ \\
\hline $\begin{array}{c}16 \mathrm{~S}- \\
\text { rDNA }\end{array}$ & Forward & GTAGGTGGCAAGCGTTATCC & 228 \\
\cline { 2 - 3 } Sa442 & Feverse & CGCACATCAGCGTCAG & \multirow{2}{*}{108} \\
\cline { 2 - 3 } & Reverse & AATCTTTGTCGGTACACGATATTCTTCACG \\
\hline
\end{tabular}

Table.2 Antibiogram trend of coagulase positive and negative Staphylococcus isolates against nine antimicrobial agents

\begin{tabular}{|c|l|l|l|l|l|l|l|}
\hline \multirow{2}{*}{$\begin{array}{c}\text { Sr. } \\
\text { No }\end{array}$} & \multirow{2}{*}{ Antimicrobial agent } & \multicolumn{2}{|c|}{ No. of isolates in CoPS group (n=12) } & \multicolumn{2}{c|}{ No. of isolates in CoNS group (n=17) } \\
\cline { 2 - 8 } & Sensitive & Intermediate & Resistant & Sensitive & Intermediate & Resistant \\
\hline 1 & Amoxy-clav* & $8(66.67 \%)$ & $1(8.33 \%)$ & $3(25.00 \%)$ & $11(64.71 \%)$ & $1(5.88 \%)$ & $5(29.41 \%)$ \\
\hline 2 & Ampi-sulbactam** & $8(66.67 \%)$ & 0 & $4(33.33 \%)$ & $9(52.94 \%)$ & $1(5.88 \%)$ & $7(41.18 \%)$ \\
\hline 3 & Ceftizoxime & $6(50.00 \%)$ & $2(16.67 \%)$ & $4(33.33 \%)$ & $11(64.71 \%)$ & $2(11.76 \%)$ & $4(23.53 \%)$ \\
\hline 4 & Ceftriaxone & $6(50.00 \%)$ & $1(8.33 \%)$ & $5(41.67 \%)$ & $8(47.06 \%)$ & 0 & $9(52.94 \%)$ \\
\hline 5 & Ciprofloxacin & $4(33.33 \%)$ & $1(8.33 \%)$ & $7(58.33 \%)$ & $9(52.94 \%)$ & $1(5.88 \%)$ & $7(41.18 \%)$ \\
\hline 6 & Enrofloxacin & $6(50.00 \%)$ & 0 & $6(50.00 \%)$ & $10(58.82 \%)$ & $1(5.88 \%)$ & $6(35.29 \%)$ \\
\hline 7 & Gentamicin & $7(58.33 \%)$ & 0 & $5(41.67 \%)$ & $11(64.71 \%)$ & 0 & $6(35.29 \%)$ \\
\hline 8 & Penicillin-G & $2(16.67 \%)$ & 0 & $10(83.33 \%)$ & $2(11.76 \%)$ & 0 & $15(88.24 \%)$ \\
\hline 9 & Tetracycline & $1(8.33 \%)$ & $1(8.33 \%)$ & $10(83.33 \%)$ & $4(23.53 \%)$ & 0 & $13(76.47 \%)$ \\
\hline
\end{tabular}

*Amoxycillin-clavulanate; **Ampicillin-sulbactam

Combination of amoxycillin-clavulanate was also most effective drug against CoNS group of mastitis pathogens along with ceftizoxime and gentamicin. Likewise, based on MIC studies, Moroni et al., (2006) also concluded that only certain $\beta$-lactamase-resistant penicillins (specifically cloxacillin) or penicillin combinations (amoxycillin plus clavulanate) were consistently effective against $S$. aureus isolated from subclinical bovine mastitis in Italy. In addition, the $\mathrm{MIC}_{90}$ for amoxycillin plus clavulanate against the $S$. aureus strains isolated from bovine mastitis was substantially lower than the $\mathrm{MIC}_{90}$ observed for ampicillin alone (De Oliveira et al., 2000). Pharmacoepidemiological study on pattern of clinical usage of veterinary antimicrobials in Northern Gujarat (India) revealed that practitioners prefer beta-lactamase inhibitors (salbactam) or $\beta$-lactamase resistant penicillins (cloxacillin) in combination of penicillins or cephalosporins to treat cases of mastitis (Patel et al., 2014). Kumar et al., (2011) reported higher susceptible to amoxicillin-clavulanate $(81.3 \%)$ of S. aureus isolates obtained from mastitic Sahiwal cattle. In present study, it was observed that both groups (CoPS and CoNS) were most resistant to penicillin-G $(83.33$ and $88.24 \%$, respectively) followed by tetracycline ( 83.33 and $76.47 \%$, respectively). Ranjan et al., (2010) also found penicillin-G with streptomycin as most resisted drugs based on antibiogram study of various isolates from 
clinical bovine mastitis from Ranchi region (Jharkhand, India). Similarly, Coagulasenegative staphylococci isolates from bovine mastitis in Argentina also exhibited the highest degree of resistance to penicillin of all antimicrobial agents tested (Gentilini et al., 2002). In present study, fluoroquinolones (ciprofloxacin and enrofloxacin) were demonstrated to be more effective in terms of susceptibility against CoNS group (52.94 and $58.82 \%$, respectively) than CoPS group (33.33 and $50.00 \%$, respectively). However, Jahan et al., (2015) from Bangladesh reported higher susceptibility $(83.33 \%)$ of raw cow milk $S$. aureus isolates to ciprofloxacin.

\section{Acknowledgement}

Authors are grateful to TVCC, Deesa and Veterinary Officers of Banas Dairy and State Animal Husbandry Department, Banaskantha district, Gujarat, for providing mastitis milk samples.

\section{References}

Al-Rubaye, S.M.H., E.F. Al-Jumaily, and Abdul-Ratha, H.A. 2016. Biofilm Production by Staphylococcus aureus isolated from Bovine Mastitis Related with Resistance to the Antibiotics. Int. J. Curr. Microbiol. App. Sci., 5(5): 33-44.

Babra, C., J.G. Tiwari, G. Pier, T.H. Thein, R. Sunagar, S. Sundareshan, S. Isloor, N.R. Hegde, S. deWet, M. Deighton and Gibson, J. 2013. The persistence of biofilm-associated antibiotic resistance of Staphylococcus aureus isolated from clinical bovine mastitis cases in Australia. Folia microbiologica, 58(6): 469-474.

Barkema, H.W., Y.H. Schukken and Zadoks, R.N. 2006. The role of cow, pathogen, and treatment regimen in the therapeutic success of bovine Staphylococcus aureus mastitis. J.Dairy Sci., 89(6): 1877-1895.

Barrow, G.I., and Feltham, R.K.A. 1993. In:
Cowan and Steel's manual for the identification of medical bacteria. $3^{\text {rd }}$ ed. Cambridge University Press, UK.

Bauer, A.W., W.M. Kirby, J.C. Sherris and Turck, M. 1966. Antibiotic susceptibility testing by a standardized single disk method. Am. J. Clin. Pathol, 45(4): 493496.

Bhagat, A.G., H.N. Kher, A.I. Dadawala, H.C. Chauhan and Chandel, B.S. 2017. Identification and characterization of methicillin-resistant Staphylococcus aureus isolated from bovine mastitis. Int. J. Curr. Microbiol. App. Sci. 6(2): 223-230.

Buchanan, R.E., and Gibbons, N.E. 1974. In: Bergey's Manual of Determinative Bacteriology. $8^{\text {th }}$ ed. Williams \& Wilkins Co., Baltimore.

CLSI. 2012. Performance standards of antimicrobial disc susceptibility test, The Clinical and Laboratory Standards Institute, M 100 S22 Vol. 32 No. 3.

Darwish, S.F., and Asfour, H.A. 2013. Investigation of biofilm forming ability in Staphylococci causing bovine mastitis using phenotypic and genotypic assays. Scientific World J., Article ID 378492, 9 pages.

De Oliveira, A.P., J.L. Watts, S.A. Salmon and Aarestrup, F.M. 2000. Antimicrobial susceptibility of Staphylococcus aureus isolated from bovine mastitis in Europe and the United States. J. Dairy Sci., 83(4): 855-863.

Du Preez, J.H., 2000. Bovine mastitis therapy and why it fails. J. S. Afr. Vet. Assoc., 71(3): 201-208.

El-Jakee, J.K., N.E. Aref, A. Gomaa, M.D. ElHariri, H.M. Galal, S.A. Omar and Samir, A. 2013. Emerging of coagulase negative staphylococci as a cause of mastitis in dairy animals: An environmental hazard. Int. J. Vet. Sci. Med. 1(2): 74-78.

Fox, L.K., T.E. Besser and Jackson, S.M. 1996. Evaluation of a coagulase-negative 
variant of Staphylococcus aureus as a cause of intramammary infections in a herd of dairy cattle. J. Am. Vet. Med. Assoc., 209: 1143-1146.

Gentilini, E., G. Denamiel, A. Betancor, M. Rebuelto, F.M. Rodriguez and De Torres, R.A. 2002. Antimicrobial susceptibility of coagulase-negative staphylococci isolated from bovine mastitis in Argentina. $J$. Dairy Sci., 85(8): 1913-1917.

Halasa, T., K. Huijps, O. Osteras and Hogeveen, H. 2007. Economic effects of bovine mastitis and mastitis management: A review. Vet. Q., 29(1): 18-31.

Jahan, M., M. Rahman, M.P. Shafiullah, S.M.Z. Haq Chowdhury, M.E. Haque, M.A.K. Talukder, and Ahmed, S. 2015. Isolation and characterization of Staphylococcus aureus from raw cow milk in Bangladesh. J. Adv. Vet. Anim. Res., 2(1): 49-55.

Krishnamoorthy, P., K.P. Suresh, S. Saha, G. Govindaraj, B.R. Shome and Roy, P. 2017. Meta-analysis of prevalence of subclinical and clinical mastitis, major mastitis pathogens in dairy cattle in India. Int. J. Curr. Microbiol. App. Sci., 6(3): 1214-1234.

Kumar, R., B.R. Yadav and Singh, R.S. 2011. Antibiotic resistance and pathogenicity factors in Staphylococcus aureus isolated from mastitic Sahiwal cattle. J. Biosci., 36: $175-188$.

Lovseth, A., S. Loncarevic and Berdal, K.G. 2004. Modified multiplex PCR method for detection of pyrogenic exotoxin genes in staphylococcal isolates. J. Clin. Microbiol, 42: 3869-3872.
Martineau, F., F.J. Picard, P.H. Roy, M. Ouellette, and Bergeron, M.G. 1998. Species-specific and ubiquitous-DNAbased assays for rapid identification of Staphylococcus aureus. J. Clin. Microbiol, 36: 618-623.

Moroni, P., G. Pisoni, M. Antonini, R. Villa, P. Boettcher and Carli, S. 2006. Antimicrobial drug susceptibility of Staphylococcus aureus from subclinical bovine mastitis in Italy. J. Dairy Sci., 89(8): 2973-2976.

Patel, H.A., S.K. Mody, H.B. Patel and Singh, R.D. 2014. Pharmacoepidemiology of clinical usage of veterinary antimicrobials in Northern Gujarat. J. Vet. Pharmacol. Toxicol, 13(2):109-111.

Pyorala, S., and Taponen, S. 2009. Coagulasenegative staphylococci - Emerging mastitis pathogens. Vet. Microbiol, 134(1): 3-8.

Ranjan, R., M.K. Gupta, S. Singh and Kumar S. 2010. Current trend of drug sensitivity in bovine mastitis. Vet. World, 3(1): 17-20.

Taponen, S., and Pyorala, S. 2009. Coagulasenegative staphylococci as cause of bovine mastitis - Not so different from Staphylococcus aureus? Vet. Microbiol, 134(1): 29-36.

Tiwari, J., C. Babra, H.K. Tiwari, V. Williams, S. de Wet, J. Gibson, A. Paxman, E. Morgan, P. Costantino, R. Sunagar and Isloor, S., 2013. Trends in therapeutic and prevention strategies for management of bovine mastitis: an overview. J. Vaccines Vaccin, 4(2): 8-11.

\section{How to cite this article:}

Singh, R.D., B.I. Prajapati, S.K. Mody, H.B. Patel, S.S. Deokar, B.A. Solanki, S.P. Desai, V.L. Solanki, P.M. Chauhan and Momin, R.R. 2017. Antibiogram of CoPS and CoNS Isolated from Bovine Mastitis in Banaskantha District of Gujarat. Int.J.Curr.Microbiol.App.Sci. 6(10): 564569. doi: https://doi.org/10.20546/ijcmas.2017.610.069 